\title{
INFLUENCE OF ENTREPRENEURIAL TRAITS ON THE PERFORMANCE OF SMALL AND MEDIUM SIZED ENTERPRISES (SMES) IN LAGOS STATE, NIGERIA
}

PATRICK S. OKONJI

$\mathrm{PhD}$

\author{
OLUFEMI O. OLAYEMI \\ $\mathrm{PhD}$
}

\author{
D. MGBE \\ MSc
}

\begin{abstract}
Factors such as political instability, government policies, infrastructural inadequacy and entrepreneurs' non-possession of relevant personal characteristics are connected on the high failure rate of small businesses in Nigeria. On the back of these identified problems the study focused on Influence of entrepreneurial traits on the performance of Small and Medium Sized Enterprises in Lagos State., Specifically, resilience, innovativeness, drive for achievement, and risk taking propensity were the entrepreneurship traits examined in relation to the performance of SMEs in Lagos state. Primary source of data through a questionnaire was used to achieve the stated objectives. Random sampling method was used to collate data of 125 entrepreneurs who participated in the study. Frequency tables and percentages were used for data presentation and the Regression analysis was used to test the formulated hypotheses, with the aid of statistical package for social sciences (version 21.0). The study summarised that there are significant relationships between the tested traits and the growth of SMEs in Nigeria. The study recommended that owner/ entrepreneurs should individually improve their skills in these critical traits' areas. In addition, the government should provide institutional support in terms of training and development. Government should also create an enabling environment for business to thrive, through provision of infrastructures.
\end{abstract}

Keywords: Nigeria, Entrepreneurial, Traits, Small and Medium Scale Enterprises, Performance

JEL code: D00, D20, D22, M20 


\section{INTRODUCTION}

The evolution of entrepreneurship is an essential and crucial phenomenon in modern business management. Entrepreneurship is a key factor that drives the global market, ensures industrial development and facilitates economic growth, which is linked and majorly driven small and medium sized enterprises (SMEs), which are regarded as agent or driving force of market economies that provides the platform for national development and economic growth in any economy (Stefanovic, Ljubodrag, \& Sloboda, 2011). SMEs are regarded as facilitators for self-reliance, by ensuring the explore of local raw materials which serve not only as tool for self-reliance for industrial development, they also generate more employment opportunities for the populace, improve investment drive in an economy and facilitate industrial development of both rural areas and urban centres (Roy \& Wheeler, 2006; Raymond, Moses, Ezenyirimba \& Otugo, 2014).

Rufai (2011) suggested that one of the major tool necessary for eradicating poverty and unemployment in Nigeria, is sensitising citizens about the importance of entrepreneurship, helping them to acquire other competencies such as resilience and self-efficacy, inculcating the entrepreneurial drive and knowledge for them to be creators of labour and not seekers of labour and finally to become successful entrepreneurs. Ezenwafor and Okoli (2014) after a thorough research in unemployment situation in the eastern part of Nigeria came up with the conclusion that it is sad that that no government in Nigeria can provide sufficient or full employment to its citizenry and the only viable option or way out is entrepreneurship. The challenges of unemployment and unemployment low standard of living occasioned by poverty have served as a push factor necessitating the need for entrepreneur to start their business in order to upgrade their standard. These start-ups / businesses are expected to have a multiplier effect by generating wealth for the entrepreneur, increase the living condition, increase national productivity and improve national growth thereby eliminating poverty in the long run. Numerous entrepreneurs are finding it difficult to survive and sustain their businesses in the country. The post COVID economic challenges will take its toll on the small scale businesses with the fluctuating rate of the dollar to Naira exchange rate, fall in the price of crude oil in the global market, high inflation rate, poor assess and inadequate capital, government policies summersaults and the general harsh economic environment in Nigeria. These issues have posed grave challenges in the management and survival of Small and Medium Enterprises initiated by entrepreneurs.

Despite the challenges associated with small scale businesses and entrepreneurship development, it is still the golden chicken that lays the golden eggs in terms of job creation, development of indigenous entrepreneurs and economic growth in Nigeria. Therefore, the will-power, self-efficacy, resilience and determination of the individual entrepreneurs come to bear. Despite the challenges of the economy and operating business environment, the resolve 
of the entrepreneur is an important factor that can shape how far a small scale business can survive and grow. It is worth investigating the extent of influence that entrepreneurship resilience and owners' characteristics, and how they affect growth and development of certain Small and medium enterprises based in Lagos. It is worth investigating the extent of influence that entrepreneurship resilience and owners' characteristics, and how they affect growth of certain Small and medium enterprises.

The key objective of the study is to assess the influence of entrepreneurship characteristics on the performance small and medium enterprises (SMEs) in Lagos, Nigeria. The specific objectives are:

1. To examine how resilience of an entrepreneur affects the performance of Small and Medium enterprises.

2. To investigate the extent to which innovativeness enhance the performance of small and medium enterprises in Nigeria.

3. To find out how the drive for achievement enhances the performance of small and medium enterprise in Nigeria.

4. To ascertain the extent to which risk taking propensity of an entrepreneur influence the performance of small and medium enterprise in Nigeria.

\section{RESEARCH HYPOTHESES}

The research hypotheses of the study are as follows:

Hypothesis One: Resilience of an entrepreneur does not promote the growth of small and medium enterprises in Nigeria.

Hypothesis Two: There is no significant relationship between innovativeness and the performance of small and medium enterprises in Nigeria.

Hypothesis Three: Drive for achievement does not enhance the performance of small and medium enterprise in Nigeria.

Hypothesis Four: Risk taking propensity of an entrepreneur does not have significant influence on the growth of small and medium enterprise in Nigeria.

The findings of this study are likely to benefit entrepreneurs, small business start-ups, small scale business industrialists, and future management researchers. Also, the government at all levels and institutions that provide support to small scale businesses will gain from this study. The study will therefore be instrumental to the knowledge and comprehension of the concept of entrepreneurship characteristics, and their influence on the growth and performance of SMEs in Nigeria. Lastly, the study will constitute a useful addition to work already done in the field of entrepreneurship and business management, thus serving as a reference for future research work. The study will be limited to the influence of entrepreneurship resilience, innovativeness, need for achievement and risk 
propensity of entrepreneurs on the growth of small and medium enterprises in Lagos, Nigeria.

\section{REVIEW OF RELEVANT LITERATURE}

\section{ENTREPRENEURSHIP}

The term 'Entrepreneurship' can be defined as discovering a business opportunity, generating resources to harness the business opportunity, and taking risk to run the business successfully (Umaru \& Obeleagu-Nzelibe, 2014). Entrepreneur is a word gotten from French word 'entrepre' which means one who undertakes revolution, transforms the all inputs into economic goods. Entrepreneurship entails starting or new organisation or revolving or being part of revitalising mature organisation in response to a perceived opportunity. The most obvious form of entrepreneurship is that of starting a new business (Esuh, 2011). For instance, Oyelola, Ajiboshin, Raimi, Raheem and Igwe (2013) points out that an entrepreneur is an individual that embarks on a new business from inception or takes over from the founding founder or inherits that venture and is capable to nurture and transform it to profitable venture. Entrepreneurship is also seen as service rendering; establishing and nurturing a service venture in response to the identified needs of people (Akanwa \& Agu, 2005).

Entrepreneurs are saddle with responsibility of ensuring social and economic development of nation and this can be done through the process of identifying of business opportunities, evaluating and selecting the most profitable venture, allocation and distribution of the necessary resources, coordination of factors of production such as other factors of production such as capital, labour and land, planning and controlling operations of the organisation, utilisation of indigenous raw materials, risk bearing, creating of employment opportunities, marketing activities for customer satisfaction, and innovation to meet with the needs of local market (Oyelola, et al., 2013). Entrepreneurship in Nigeria could be traced when people in the rural areas and peasant farmers in various communities were producing more yields than they anticipated, as such; they would need for exchange as a result of the fact that when they produce, they was great need for their farm produce to sold and exchanged for some form of medium of exchange (goods for goods, goods for money) with people that needed these farm produce. (Oyelola, et al., 2013)

\section{SMALl AND MEDIUM SCALE ENTERPRISES}

According to International Labour Organization (2005), there is no globally unified agreed definition of Small and Medium Enterprise (SMEs). There have been about 50 definitions in about 75 countries to define what a small and medium enterprise is based on the economic and social condition that is prevalent in that country. For instance, the Economic commission (2016) defines enterprises as 
entities which employ between one and ten persons and a turnover of less than thirty million Euros. While medium-sized enterprise is one with less than two hundred employees and an annual turnover of less than fifty million Euros. In Nigeria, the Small and Medium Industries and Equity Investment Scheme (SMIEIS) defines small and medium enterprise base on the following basis. Asset: Its total assets base is less than 200 million naira (which equals $\$ 1.43$ million) excluding land and working capital, Staff employed: The number of staff employed are not less than 10 persons and with the number of staff employed not less than 10 (Sanusi 2009; Sule, 2006).

\section{ENTREPRENEURIAL CHARACTERISTICS}

Successful entrepreneurs possess certain individual characteristics such as being hopeful, visionary, disciplined, tenacious, resilient, accommodating, passionate, focused, willing to learn, ethical, hard-working and having initiative, drive for success, risk tolerance, integrity is a major key characteristics, and 'I can do it spirit' (Tobak, 2013; Ezenwafor, 2013). Patricio and Neyland (2013), opine that for a successful entrepreneur to succeed and withstand environmental shocks, he or she must possess certain personal traits / characteristics for this to be so, they include he or she must goal oriented, committed to the business, take pro-active measures when needed, thriving in uncertainty, innovation must be continuously searched for to set him or her apart, he or she must be passionate among the business, being creative and innovative,, confident, he or she must be a risk taker, to listen and learn.

\section{ENTREPRENEURSHIP RESILIENCE}

Resilience is comparatively a present day concept in the social sciences (Martin, 2012) which also connotes self-efficacy and determination of an individual to succeed against all odd. Resilience is seen as the tendency to respond to disturbance without regressive behaviour (Horne \& Orr, 1998). Some scholars define resilience, as attributes of a system's strength to withstand opposition or "bounce back" (Dawley, Pike \& Tomaney, 2010, p. 652) or withstand external crises (Simmie \& Martin, 2010) and thus generate consistent economic growth. Most studies that has been conducted has placed much emphasis on the cognitive resilience and little emphasis on the resilience on the system, thereby creating a gap in literature(Ayala \& Manzano, 2014).

In explaining resilience to entrepreneurship, an entrepreneurial individual and firm applies resilience in ensuring creativity and organising skills to survive difficult times in the business environment and to stand against shocks that are prevalent in the socio-economic climate of operation (Johannisson, 2011). Like a more established firm such as multinational company or other large scale business organisation, the chances of an unforeseen circumstance are ever-present with a small scale business or individual entrepreneur who possibly have little or 
no organisational structure, little capital base and other limitations such as human and material resources (Vogus \& Sutcliffe, 2007). The ability of an entrepreneur to react and adapt to unforeseen and possibly environmental shocks as a lot to determine an organisation relevance and survival (Gutschick \& Bassiri Rad, 2003). More established companies that have the resources and financial might, expertise, structure to absorb and withstand external shocks (Gilbert, 2005; Shane, 2003; Sine, Mitsuhashi, \& Kirsch, 2006; Morrisse \& Ingram, 2016).

\section{INNOVATIVENESS}

Innovativeness can be seen as the length to which an individual adopts innovation in the execution of a project, idea that creates value or task. Innovativeness is also seen as a component of human personality or characteristics of a person to follow new ways of doing things, taking decisions and solving complex problems (Kirton, 2003; Marcati, Guido, \& Peluso, 2008). It entails generating brilliant innovation and bringing to reality creative ideas; it is the creation of new value and turning ideas into success. Innovativeness is the transformation of ideas into knowledge and knowledge into capital, without which a venture will not be successful or run out of steam (Okpara, 2007).

One of the critical performance indices of a firm is innovativeness. As an entrepreneurship characteristic innovativeness, riding on the wings of opportunity and being creative in the identifying and exploiting of opportunities (Omerzel, 2016). Drucker (1985) sees innovation is seen as the engine house by that allows entrepreneurs seek and exploit opportunities. Innovativeness which is described as ability to find originality towards the getting way of action also includes the preference of entrepreneurs to engage in creativity and experimentation (Rauch, 2010). A major key which is innovativeness is very important to entrepreneurs because it allows them to recognise important opportunities and seek for new and better ways of accomplishing objectives and achieving goals (Ward, 2004). Thus, innovativeness in entrepreneurs has been predicted to aid performance and growth of businesses. (Olayemi, 2014; Olayemi, \& Okonji, 2016).

\section{DRIVE FOR ACHIEVEMENT}

The drive for achievement alludes to an individual's aim for significant accomplishment, ability to learn quickly, and to achieve something that you planned to do or attempted to do. Entrepreneurs have been theorised to possess a strong need for achievement and motivation (Kerr, Kerr, \& Xu, 2017). The McClelland need for achievement is a character originating from (1985) "acquired-needs theory" and this is a dominant need affecting a person behaviour in the workplace. Research has established that a high need for achievement predicts entry into entrepreneurship (Korunka, Frank, Lueger \& . Mugler, 2003). Frank, Lueger \& Korunka (2007) affirms that the need for achievement is a trait 
that alludes an individual's entrepreneurial drive and keeps them going in difficult and changing business environment. It has also been discovered that the need for achievement is strongly linked to entrepreneurship intent, and business performance (Collins, Hange, \& Locke, 2004). Entrepreneurship trait of drive for achievement has been found to be a determinant of business success and growth of business endeavours (Karabulut, 2016).

\section{RISK TAKING PROPENSITY}

Martijn and Daan (2017) define risk as uncertainty whose probability of occurrence and payoffs can be quantified. Risk taking propensity as an important characteristic of entrepreneurship, entrepreneurs are different from others by their acumen based on their understanding and acting based on luck/lucky chance irrespective unpredictability and complexities, they face. Entrepreneurs are those who are known for handling risk and taking risky opportunities (Kerr, Kerr, \& Xu, 2017).Khilstrom and Laffont (1979) were able to establish a theory that explains why most risk seekers are likely to be entrepreneurs and those that score (risk averters) are likely to be employees because they avoid risk and fear failure. Risk taking disposition is a state in which an individual is able to handle risk and withstand these risky situations which are mostly taken for prestige, for the survival of their business, to harness key opportunities with reduced risk and most likely favourable result (Karabulut, 2016).

\section{ORgANISATIONAL PERFORMANCE}

Organisational performance is an assessment of the extent to which an entity achieved its stated goals and objectives in the service of its stakeholders. Moullin (2003) assert that performance is primarily concerned with assessing how an organisation is being or has been administered with respect to the values it delivers for customers and other stakeholders. An organisation is deemed to have performed well when it meets the expectations of both the primary and secondary stakeholders. The concepts of effectiveness and efficiency have been traditionally used to measure organisational performance. According to Neely and Adams (2001) effectiveness measures the extent to which an organisation meets promised stakeholders' needs. While efficiency focuses on the input-output relationship in meeting stakeholders needs. Researchers studying organisational performance have used both subject and objective criteria (Richard, Devinney, Yips and Johnson, 2009). The objective or quantitative criteria include growth in sales, revenue, profit, market share and productivity. On the other hand, qualitative or subjective criteria are customer satisfaction, goals achievement, employee satisfaction and behaviour, quality of leadership, innovation among others (Zimon 2018 \& Gupta and Batra 2016).

Frank and Roessl (2015) posit that the difficulty in obtaining objective data such as income statements in SMEs make it more convenient to resort to 
subjective indicators in SMEs performance measurement. The inability of SMEs to establish performance measurement and needed culture for the collection of decision data compel researchers to rely on subjective rather than objective measures of performance.(Heilbrunn, Rozenes and Vitner, 2011 \& Dess and Robinson,1984). Besides, there is an emerging consensus among several authors that subjective criteria could be more reliable and credible for measuring SMEs performance in the emerging and developing economies (Lukas, Tan and Hult, 2001, Brouthers, 2002). This is even more instructive in Nigeria where income statements are padded to meet the requirements of specific stakeholders.

The theoretical foundation for this study is active learning. Active Learning Model was advanced by Erickson and Pakes (1995), opines that a firm or business has a greater chance of survival, when it adequately by investing raise their effectiveness and efficiency through acquiring the appropriate training and formal education that would actually facilitates it competitiveness both externally and internally, and therefore enhance its growth and its ability o respond and withstand various environment variables that might likely impair its operations and success, both the government and the individual entrepreneurs have a serious role to play in this. The government is expected to provide a conducive and supportive business environment for these SMEs that will encourage business and entrepreneurs of Small and Medium Scale enterprises are also expected to learn and gain the required experience through training and formal education which would help it have a competitive advantage. And with these two factors in place entrepreneurial firms and business stands a greater chance of growing, and experiences sustainable development (Agwu \& Emeti, 2014). Nigeria then stands a chance in achieving its entrepreneurial goals, generating employment, if not full and enhancing economic development only when and development of entrepreneurship characteristics and appropriate investments are put into the management of their businesses through active learning.

Another scholar Lebusa (2011) also conducted a research to ascertain the relationship that existed students' performance and their level of efficacy, and the result showed positive significant relationship existed between the students' performance and their level of efficacy. On the contrary, Powers (1991) had a contrary believed that self-efficacy enhanced an individual's optimism which has a negative effect on the level an individual performances and that people tend to put in lesser effort when they have a high confidence of achieving success $\mathrm{He}$ believed that people make less effort when there is a confidence of when they know they can be successful in achieving a goal or task. Bandura and Jourden (1991) also carried out a study and discovered that self-efficacy decreases an individual's performance because when he or she believes he or she can do or has the confidence of being able to perform a particular task this might prompt that person to put believing that even that that level of effort he or she can still achieve maximum result. Stone (1994) discovered that an individual's overestimation of his or her 'can do spirit' and abilities, which will produce overconfidence which can also help to reduce his or her actual performance. 
Vancouver, Thompson, Tischner, and Putka (2001) conducted two phases to determine the relationship that exist between self-efficacy and a person's performance. The first which was conducted with 56 undergraduates came out positive, that there actually self-efficacy actually affects an individual's performance, while the other phase of the study which was conducted for another set of 185 undergraduates carried out in other to replicate the first studies to show if there was actually consistency between the first and second studies, the result of the second came out negative in tandem with the first research, which showed that performance facilitates self-efficacy and not the other way round, which challenged previous studies conducted by other scholars on the most accepted relationship that existed between self-efficacy and individual performance.

Another study was carried out by Vancouver, Thompson, Tischner, and Putka (2002) to study the relationship between self- efficacy and an individual performance. This time, they used computer game to carry out this study on undergraduates of an academic institution on 2 experimental levels. In the first study participant recipients were allowed to undertake any 10 experiment trials before the actual self-efficacy test was conducted, and was used to measure the relationship between the two variables. The studies later discovered that there was not positive significant relationship between self-efficacy and individual's performance, but rather self-efficacy decreased individual's performance instead of enhancing it. In the second study that was also carried on 104 undergraduates, there was still a negative relationship between self-efficacy and individual performance which was in tandem with the first study been carried out. Chen, Greene and Cride (1998) developed an instrument that was used to assess self-efficacy with dimensions such as financial control skills, innovation, marketing,risk-taking and management, while DeNobel, Jung and Ehrlich (1999) also developed an entrepreneurial domain scale in other to measure an entrepreneur intention and action and the result showed that there was relationship self-efficacy and entrepreneur intentions and performance.

Contrary to findings on the relationship between risk taking and performance, Egele, Muhammed and Mutanyo (2018) reported that entrepreneurial risk taking does not have positive influence on SMEs' performance studied firms in Kano, Nigeria. Similarly, Bar and Kunday (2014) in a study to determine the role of entrepreneurial traits and human capital on internalisation degree of SMEs in Turkey found that the propensity for risk taking does not have any positive influence on internalisation of a company. Sidek and Zainol (2014)'s work on the impact of psychological traits and business performance of entrepreneurs in Malaysia, entrepreneurs with higher performance exhibited higher achievement needs and higher propensities for risk taking than their low performing peers. Zhao, Seibert, and Hills (2005) studies were conducted to examine the relationship that exist between self-efficacy measured in entrepreneurial specific domain and entrepreneurial intentions and actions. The study was conducted on $778 \mathrm{MBA}$ students in 5 different universities mainly at their Business Facilities and was conducted at two phases, firstly when they were coming into the institution and 
before they graduated. And the end of the research it was discovered that there was a positive significant relationship between entrepreneurial specific domain and entrepreneurial intentions and actions to create new starts up, business and manage them

Brice and Spencer (2007) another study which was conducted on graduating students in an institution in order to analyse the relationship between selfefficacy and the ability to manage a firm adequately. The result of the study discovered that there was a positive significant relationship between self-efficacy and effective management, and those entrepreneurs that scored high in selfefficacy did better at effectively managing their business. Entrepreneurs that did not possess self-efficacy, was seen as a hindrance and barrier that impeded their ability to effectively manage well. Hmieleski and Baron (2008) another study was conducted by them to investigate the relationship between self-efficacy and enterprise/ business growth. The reverse was the case compared to other studies been carried out. They discovered that there was a negative relation between the two variables, there asserting that self-efficacy reduces a firm growth under certain moderating variables and conditions investigated the effect of self-efficacy on venture growth and results proved a positive effect. In this study, self-efficacy was measured in entrepreneurial specific domain and firm performance was the focus.

\section{METHODOLOGY}

This study adopted the survey design. The targeted population for this study consists of all registered Small and Medium Enterprises (SMEs), both of which have been in operations for a minimum of five years in Lagos, Nigeria, which has been described as the commercial centre of Nigeria with the highest SMEs (CBN, 2010). The sampling frame of the study consists of owners of selected small scale businesses in the Mainland area of Lagos metropolis. The systematic random sampling was employed in selecting 125 SMEs both in service (65\%) and manufacturing (35\%) sectors by the researcher. 30 of those polled were females while 95 of them were females. The age brackets were 30-50 years while the start-up capital ranges between Five hundred Naira $(\# 500,000.00)$ and Ten million Naira $(\# 10,000,000.00)$. The primary data were collected through wellstructured questionnaires adapted from various authors. Perseverance/ resilience (Duckworth and Quinn 2009), Innovativeness (Janssen, 2000), Achievement (Lynn, 1969) and Risk taking propensity (Meertens and Lion, 2008). Organisational performance questionnaire was developed by the authors. It was measured through questions on customer satisfaction relative to competitors, customer satisfaction, repeat purchases, market share growth among others.

To determine the validity of the instrument, the questionnaire was subjected to content validity where the opinion of scholars in the department of Business Administration, faculty of management sciences. For the purpose of the reliability 
of the instrument, thirty-five (35) copies of the questionnaire were administered as a pilot study test while the reliability analysis was carried out using Statistical Package for Social Scientist (SPSS 21 Version).The Cronbach's Alphas are: Resilience 0.869. Innovativeness 0.76, Achievement 0.82, Risk taking 0.70 and Performance 0.681 respectively. Data were analysed using Descriptive statistics and inferential statistics. Regressions were used to establish relationships between the dependent and the independent variables.). The Statistical Package for Social Science (SPSS) version 21 was used to analyse the data obtained. The outputs of the analysis were presented in tables and figures.

\section{ANALYSIS AND INTERPRETATIONS}

Hypothesis one: Perseverance/resilience does not promote the growth of SME's in Nigeria.

Table 1

Regression results for hypothesis one

\begin{tabular}{|c|c|c|c|c|c|c|c|c|c|c|}
\hline \multirow[t]{2}{*}{ Model } & \multicolumn{2}{|c|}{$\begin{array}{l}\text { Unstandard- } \\
\text { ised } \\
\text { Coefficients }\end{array}$} & \multirow{2}{*}{$\begin{array}{c}\begin{array}{c}\text { Standard- } \\
\text { ised Co- } \\
\text { efficients }\end{array} \\
\text { Beta } \\
\end{array}$} & \multirow[t]{2}{*}{$\mathbf{t}$} & \multirow[t]{2}{*}{ Sig. } & \multirow[t]{2}{*}{$\mathbf{F}$} & \multirow[t]{2}{*}{$\mathbf{R}$} & \multirow[t]{2}{*}{$\mathbf{R}^{2}$} & \multirow{2}{*}{$\begin{array}{c}\text { Adj. } \\
\mathbf{R}^{2}\end{array}$} & \multirow{2}{*}{$\begin{array}{c}\text { Std. } \\
\text { Error } \\
\text { of the } \\
\text { Estimate }\end{array}$} \\
\hline & B & $\begin{array}{c}\text { Std. } \\
\text { Error }\end{array}$ & & & & & & & & \\
\hline (Constant) & 1.030 & .244 & & 2.211 & .012 & \multirow[b]{2}{*}{70.149} & \multirow[b]{2}{*}{$.671^{\mathrm{a}}$} & \multirow[b]{2}{*}{.450} & \multirow[b]{2}{*}{.449} & \multirow[b]{2}{*}{.34219} \\
\hline $\begin{array}{l}\text { Perseverance/ } \\
\text { resilience }\end{array}$ & .543 & .151 & .671 & 6.326 & .000 & & & & & \\
\hline
\end{tabular}

a. Dependent Variable: (growth of SME)

Results obtained show that the coefficient of regression $\mathrm{R}=0.671$ while the coefficient of determination $\left(\mathrm{R}^{2}\right)$ is 0.449 . This means that the value of the dependent variable can be explained by about $49 \%$ percent of the independent variable. Furthermore the F-statistic (70.149) is significant at 5\% level since the probability of its value $(0.000)$ is lesser than the 0.05 level of significance. This simply implies that the model is statistically significant, based on this, the $\mathrm{H}_{1}$ is rejected and resilience significantly promotes growth of SME's in Nigeria.

Hypothesis Two: There is no significant relationship between innovativeness and performance of SME's in Nigeria.

Table 2

Regression results for hypothesis two

\begin{tabular}{|c|c|c|c|c|c|c|c|c|c|c|}
\hline \multirow{2}{*}{ Model } & \multicolumn{2}{|c|}{$\begin{array}{c}\text { Unstandard- } \\
\text { ised Coeffi- } \\
\text { cients }\end{array}$} & \multirow{2}{*}{\begin{tabular}{|c|}
$\begin{array}{c}\text { Standard- } \\
\text { ised Co- } \\
\text { efficients }\end{array}$ \\
Beta
\end{tabular}} & \multirow[t]{2}{*}{$\mathbf{t}$} & \multirow{2}{*}{ Sig. } & \multirow[t]{2}{*}{$\mathbf{F}$} & \multirow[t]{2}{*}{$\mathbf{R}$} & \multirow{2}{*}{$\mathbf{R}^{2}$} & \multirow{2}{*}{$\underset{\mathbf{R}^{2}}{\text { Adj. }}$} & \multirow{2}{*}{$\begin{array}{l}\text { Std. Error } \\
\text { of the } \\
\text { Estimate }\end{array}$} \\
\hline & B & $\begin{array}{l}\text { Std. } \\
\text { Error }\end{array}$ & & & & & & & & \\
\hline (Constant) & 1.112 & .401 & & 3.124 & .000 & \multirow{2}{*}{42.225} & \multirow{2}{*}{$.785^{\mathrm{a}}$} & \multirow{2}{*}{.616} & \multirow{2}{*}{.614} & \multirow{2}{*}{.135241} \\
\hline Innovativeness & 1.341 & .103 & .785 & 7.345 & .000 & & & & & \\
\hline
\end{tabular}

a. Dependent Variable: (performance of SME's) 
Table 2 shows that $\mathrm{R}$ and The $\mathrm{R}$-squared are 0.785 and 0.616 respectively. This means that there was $61.6 \%$ variation in SME's performance as a result of entrepreneurial innovativeness. Furthermore the F-statistic (42.225) is significant at $5 \%$ level since the probability of its value (0.000) is lesser than the 0.05 level of significance. This simply implies that the model is statistically significant, hence, $\mathrm{H}_{2}$ is rejected and there is a significant relationship between innovativeness and performance of SME's in Nigeria.

Hypothesis Three: There is no significant relationship between entrepreneurial Drive for Achievement and SME's performance.

Table 3

Regression Results For hypothesis three

\begin{tabular}{|c|c|c|c|c|c|c|c|c|c|c|}
\hline \multirow[t]{2}{*}{ Model } & \multicolumn{2}{|c|}{$\begin{array}{c}\text { Unstandard- } \\
\text { ised Coeffi- } \\
\text { cients }\end{array}$} & \multirow{2}{*}{\begin{tabular}{|c|}
$\begin{array}{c}\text { Standard- } \\
\text { ised Co- } \\
\text { efficients }\end{array}$ \\
Beta \\
\end{tabular}} & \multirow[t]{2}{*}{$\mathbf{t}$} & \multirow[t]{2}{*}{ Sig. } & \multirow[t]{2}{*}{$\mathbf{F}$} & \multirow[t]{2}{*}{$\mathbf{R}$} & \multirow[t]{2}{*}{$\mathbf{R}^{2}$} & \multirow{2}{*}{$\underset{\mathbf{R}^{2}}{\text { Adj. }}$} & \multirow{2}{*}{$\begin{array}{l}\text { Std. Error } \\
\text { of the } \\
\text { Estimate }\end{array}$} \\
\hline & B & $\begin{array}{l}\text { Std. } \\
\text { Error }\end{array}$ & & & & & & & & \\
\hline (Constant) & 1.349 & .261 & & 5.170 & .000 & \multirow[b]{2}{*}{129.495} & \multirow[b]{2}{*}{$.701^{a}$} & \multirow[b]{2}{*}{.491} & \multirow[b]{2}{*}{.488} & \multirow[b]{2}{*}{.57945} \\
\hline $\begin{array}{l}\text { Drive for } \\
\text { achievement }\end{array}$ & .678 & .060 & .701 & 11.380 & .000 & & & & & \\
\hline
\end{tabular}

a. Dependent Variable: (performance of SME's)

The table shows that value of $\mathrm{R}$ is while $\mathrm{R}$-squared is 0.491 . This stipulated that the $49.1 \%$ variation in SME performance can be explained by variations in drive for achievement. Furthermore the F-statistic (129.495) is significant at $5 \%$ level since the probability of its value (0.000) is lesser than the 0.05 level of significance. This simply implies that the model is statistically significant; hence, $\mathrm{H}_{3}$ is rejected and there is a significant relationship between entrepreneurial Drive for Achievement and SME's performance.

Hypothesis Four: Degree of Risk taking Propensity does not influence SME's performance

Table 4

Regression results for hypothesis four

\begin{tabular}{|c|c|c|c|c|c|c|c|c|c|c|}
\hline \multirow[t]{2}{*}{ Model } & \multicolumn{2}{|c|}{$\begin{array}{c}\text { Unstandard- } \\
\text { ised Coeffi- } \\
\text { cients }\end{array}$} & \multirow{2}{*}{$\begin{array}{c}\begin{array}{c}\text { Standard- } \\
\text { ised Co- } \\
\text { efficients }\end{array} \\
\text { Beta }\end{array}$} & \multirow[t]{2}{*}{$t$} & \multirow[t]{2}{*}{ Sig. } & \multirow[t]{2}{*}{$\mathbf{F}$} & \multirow[t]{2}{*}{$\mathbf{R}$} & \multirow[t]{2}{*}{$\mathbf{R}^{2}$} & \multirow{2}{*}{$\underset{\mathbf{R}^{2}}{\text { Adj. }}$} & \multirow{2}{*}{$\begin{array}{l}\text { Std. Error } \\
\text { of the } \\
\text { Estimate }\end{array}$} \\
\hline & B & $\begin{array}{l}\text { Std. } \\
\text { Error }\end{array}$ & & & & & & & & \\
\hline (Constant) & 2.840 & .231 & & 12.269 & .000 & & & & & \\
\hline $\begin{array}{l}\text { Degree of } \\
\text { risk taking } \\
\text { propensity }\end{array}$ & .402 & .052 & .553 & 7.676 & .000 & 58.919 & $.553^{\mathrm{a}}$ & .305 & .300 & .53448 \\
\hline
\end{tabular}

a. Dependent Variable: (SME’s performance)

From the table $\mathrm{R}$ is 0.553 while $\mathrm{R}$-squared is 0.305 . This means that there was $30.5 \%$ variation in SME performance can be explained by variations in degree 
of risk taking propensity. Furthermore the F-statistic (58.919) is significant at $5 \%$ level since the probability of its value (0.000) is lesser than the 0.05 level of significance. This simply implies that the model is statistically significant; hence, $\mathrm{H}_{4}$ is rejected and the Degree of Risk taking Propensity does influence SME's performance.

\section{CONCLUSIONS AND RECOMMENDATIONS}

The progress of a nation depends on the quality of entrepreneurship and the characteristics of entrepreneurs willing to bear the business risk. Entrepreneurship development has become a main source of development, a key driver of economic and social development, as entrepreneurs produce new products to the market with their ideas, establish businesses, and mobilise resources associating with financial, social and risk. The efforts by entrepreneurs and the level of entrepreneurship resilience to weather the storm of businesses in Nigeria is critical to economic development, given that 'white collar' jobs are shrinking from the government and private sector. The study has shown that innovativeness, perseverance, risk taking propensity and drive for achievement are critical entrepreneurship characteristics that entrepreneurs should possess, in order to withstand the pressures from the business environment and achieve business growth. The combination of entrepreneurial traits and a favourable macro-economic environment is a sine qua non for optimum performance of small and medium scale enterprises in Nigeria. Entrepreneurs/ owners must possess a reasonable amount of these traits to successful manage their enterprises. The willingness to take risk is a fundamental requirement for entrepreneurship and small and medium scale enterprises development. Owner/ managers must be willing to stake their resources in an uncertain and complex business environment. Innovation is required to meet the ever changing needs of the stakeholders. The ability to innovate helps the business to renew itself and remain tops in the competitive environment. The need for achievement is necessary to motivate the entrepreneurs towards higher performance. While resilience is required in the face of challenges the business will face. The environment will throw up challenges requiring the tenacity of the entrepreneur to weather the storms of the environment.

The study has exposed entrepreneurship resilience and owners' characteristics to explain business development and survival of the small-scale business in the economy. The study recommends the owner/entrepreneurs should individually improve their skills in these critical traits' areas. In addition, the government should provide institutional support in terms of training and development. Agencies such SMDAN should be mandated to provide regular workshops to identify the level of traits possessed by owner/ managers and nurture them to the fullest. Entrepreneurs should be schooled on the qualitative and quantitative means of risk evaluation, on the need to set realistic and not over ambitious goals 
and the ability to identify fundamental changes in the environment requiring strategic shift instead of hanging in ignorantly to their destruction. The provision of support policies will be a good complement by the government.

\section{REFERENCES}

Akanwa, P. U., \& Agu, C. N. (2005). Entrepreneurship: Theory and practice in Nigeria. Owerri, Resources Development Centre.

Ayala, J. C., \& Manzano, G. (2014). The resilience of the entrepreneur. Influence on the success of the business. A Longitudinal Analysis, Journal of Economic Psychology, $42,126-135$.

Bandura, A. \& Jourden, F. J. (1991). Self regulatory mechanisms governing the impact of social comparison on complex decision making.. Journal of Personality and Social Psychology, 60(6), 941-951.

Bar, E. and Kunday, O. (2014)., Investigating the role of entrepreneurial traits and human capital on internalization degree of small and medium enterprises in Turkey. International Journal of Business and Social Sciences, 5(2), 192-201.

Brice, J., \& Spencer, B. (2007). Entrepreneurial Profiling: A decision policy analysis of the influence of entrepreneurial self-efficacy on entrepreneurial intent. Academy of entrepreneurship Journal, 13 (2), 47-67.

Chen, C. C., Greene, P. G., \& Crick, A. (1998). Does entrepreneurial self-efficacy distinguish entrepreneurs from Managers? Journal of Business Venturing, 13, 295-316.

Collins, C. J., Hange, P. J. \& Locke, E. A. (2004). The relationship of achievement motivation to entrepreneurial behavior: A meta-analysis. Human Performance, 17, 95-117.

Dawley, S., Pike, A., \& Tomaney, J. (2010). Towards the resilient region? Local Economy 25(8), 650-667.

DeNobel, N. F., Jung, D., \& Ehrlich, S. B. (1999). Entrepreneurial self-efficacy: The development of a measure and its relationship to entrepreneurial action. In Reynolds, R. D. Bygrave, W. D., Manigart, S., Mason, S., Meyer, G. D., \& Sapienze, H. J. (eds). Frontiers of Entrepreneurship Research. Waltham, MA, P \& R Publications.

Drucker, P. (1985). Innovation and entrepreneurship: Practice and principles. New York, Harper and Row.

Duckworth, A. L. and Quinn, P. D. (2009). Development and validation of the short grit scale (GRIT-S). Journal of Personality Assessment, 91(2), 166-174.

Egele, A. C., Muhammad, K. and Mutanyo, J. (2018). Entrepreneurial risk taking and performance of small and medium scale enterprises(SMEs) in Kano Nigeria. Journal of Social Sciences, 4(3), 213-224.

Ericson, R., \& Pakes, A. (1995). Markov-perfect industry dynamics: A framework for empirical work, The Review of Economic Studies, 62(1), 53-82.

Ezenwafor, J. I. (2013). Adequacy of exposure to entrepreneurship management skills as perceived by graduating business education students of tertiary institutions in Anambra state. International Journal of Adult Education Studies, 2(1), 1-13.

Ezenwafor, J. I., \& Okoli, C. I. (2014). Assessment of personal characteristics needed to become successful entrepreneurs by managers of small \& medium enterprises in Anambra and Enugu States, Journal of Emerging Trends in Economics and Management Sciences, 5(7), 51. 
Frank, H., and Roessl, D. (2015). Problematization of entrepreneurial SME management as a field of research: Overcoming the size-based approach. Review of managerial Science, 9(2), 225-240.

Frank, H., Lueger, M., \& Korunka, C. (2007). The significance of personality in business startup intentions, startup realization and business success. Entrepreneurship \& Regional Development, 19(3), 227-251.

Gilbert, C. G. (2005). Unbundling the structure of inertia: Resource versus routine rigidity, Academy of Management Journal, 48(5), 741-763.

Gupta, V. K., and Batra (2016). Entrepreneurial orientation and firm performance in Indian SMEs: Universal contingency perspectives. International Small Business Journal: Researching Entrepreneurship, 34(5), 660-672.

Gutschick, V. P., \& Bassirirad, H. (2003). Extreme events as shaping physiology, ecology, and evolution of plants: Toward a unified definition and evaluation of their consequences, New Phytologist, 160(1), 21-42.

Hmieleski, K. M., \& Baron, R. A. (2008). Entrepreneurs optimism and new venture performance: A social cognitive perspective. Academy of Management Journal, 52(3), 473-488.

Jenssen, O. (2000). Job demands perceptions of efforts-rewards fairness and innovative work behaviour. Journal of Occupational and Organizational Psychology, 73(3), 287-302.

Johannisson, B. (2011). Towards a practice theory of entrepreneuring, Small Business Economics, 36(2), 135-150.

Horne, M. J., and Orr, J. (1990). Assessing behaviour that creates resilient organizations. Employment Relations Today, 24, 29-39.

Karabulut, A. T. (2016). Personality traits on entrepreneurial intention. Procedia-Social and Behavioral Sciences, 229, 12-21.

Kerr, S. P., Kerr, W. R., \& Xu, T. (2017). Personality Traits of Entrepreneurs: A Review of Recent Literature (No. w24097). National Bureau of Economic Research.

Kihlstrom, S., and Laffout, J. J. (1979). A general equilibrium entrepreneurial theory of firms formation based on risk aversion. Journal of Political Economy, 87(4), 719-748.

Kirton, J. M. (2003). Adaption-innovation in the context of Diversity and Change. London: Routhledge.

Korunka, C., H., Frank, M. Lueger, \& Mugler, J. (2003). The entrepreneurial personality in the context of resources, environment, and the startup process. A configurationally approach. Entrepreneurship Theory and Practice, 28(1), 23-42.

Lebusa, M.J. (2011). Does entrepreneurial education enhance undergraduate students' entrepreneurial self efficacy? A case at one Technology University in South Africa, China and US Business Review, 10(1), 53-64.

Lynn, R. (1969). An achievement motivation questionnaire. British Journal of Psychology, 60(4), 529-534.

Marcati, A., Guido, G., and Peluso, A. M. (2008). The role of SME entrepreneur's innovativeness and personality in the adoption of innovation. Research Policy, 37(9), 1579-1596.

Martijn, B., and Daan, W. (2017). Entrepreneurship risk perception and firm performance. Utrecet university School of Economics, Discussion paper series, $17-04$.

Martin, R. (2012). Regional economic resilience, Hysteresis and recessionary shocks, Journal of Economic Geography, 12(1), 1-32.

McClelland, D. C. (1985). Human Motivation. Scott Foresman, Glenview, IL. 
Meertens, R. M., and Lion, R. (2008). Measuring an individual's tendency to take risk: The risk propensity scale. Journal of Applied Social Psychology, 38(6),1506-1520.

Morisse, M., \& Ingram, C. (2016). A mixed blessing: Resilience in the entrepreneurial socio-technical system of Bitcoin. Journal of Information Systems and Technology Management, 13(1), 3-26.

Moullin, M. (2003). Defining performance measurement. Perspective on performance, 2(2), 3-15.

Neely, A., and Adams, C. (2001). The performance perspective. Cost Management, 15(1), 7-19.

Okpara, F. O. (2007). The value of creativity and innovation in entrepreneurship. Journal of Asia Entrepreneurship and Sustainability, 3(2), 1.

Olayemi, O. O. (2014). Entrepreneurial Orientation Dimensions as Determinants of Business Performance in Nigeria, Unpublished Doctoral Dissertation, University of Lagos, Akoka Yaba

Olayemi, O. O., and Okonji, P. S. (2016). Entrepreneurial orientation dimensions as determinants of business performance in Nigeria, UNILAG Journal of Business, Vol. 2, No. 2. pp. 13-25, University of Lagos.

Omerzel, D. G. (2016). The impact of entrepreneurial characteristics and organisational culture on innovativeness in tourism firms. Managing Global Transitions, 14(1), 93.

Oyelola, O. T., Ajiboshin, I. O., Raimi, L., Raheem, S., \& Igwe, C. N. (2013). Entrepreneurship for sustainable economic growth in Nigeria. Journal of Sustainable Development Studies, 2(2).

Patricio, A., \& Neyland, S. (2013). 10 important personal characteristics of entrepreneurs.Accessed from www.hiscox;com/small-business-insurance blog 10 on $8^{\text {th }}$ April, 2014.

Powers, W. T. (1991). Commentary on Bandura's Human Agency.American Psychologists, 46, 151-153.

Rauch, A. (2010). Dispositions of entrepreneurs: Exploring entrepreneurs' personality characteristics. In Lukes, M. Laguna, M. (Eds.), Entrepreneurship: A Psychological Approach, Prague, Oeconomica.

Raymond, A. E., Moses, C. O., Ezenyirimba, E., \& Otugo, N. E. (2014). The appraisal of entrepreneurship and SME on sustainable economic growth in Nigeria. Scholars Journal of Economics, Business and management, 1(8), 367-372.

Richard, P. J. T., Devinney, G., Yips, S., and Johnson, G. (2009). Measuring organizational performance: Towards methodological best practices. Journal of management, $35(3), 718-724$.

Roy, M. A., \& Wheeler, D. (2006). A survey of micro enterprise in urban West Africa: Drivers shaping the sector, Development in Practice, 16(5), 452-464.X

Rufai, R. A. (2011). Why we set up entrepreneurship studies in varsities. Daily Sun, Tuesday, February 8, 36.

Sammie, J., and Martin, R. (2010). Economic resilience of regions: towards an evolutionary approach. Cambridge Journal of Regions, Economy and Society, 3(1), $27-43$.

Sanusi, A. (2009). Small and medium scale enterprises in Nigeria: The problems and prospects. Paper presented at Institute of Directors on entrepreneurial skills acquisitionand economic development, Lagos.

Shane, S. (2003). A general theory of entrepreneurship: The individual-opportunity nexus, Cheltenham, UK, E. Elgar. 
Sidek, S., and Zainol, F. A. (2014). Psychological traits and business performance of entrepreneurs in small construction industry in Malaysia. International Business Management Journal, 2(1), 170-185.

Sine, W. D., Mitsuhashi, H., \& Kirsch, D. A. (2006). Revisiting burns and stalker: Formal structure and new venture performance in emerging economic sectors, Academy Of Management Journal, 49(1), 121-132.

Stefanovic, I., \& Milosevic, D. M. (2011). Significance and development problems of SMEs in contemporary market economy.Serbian Journal of Management, 4(1), $127-136$.

Stefanovic, I., Ljubodrag, R., \& Sloboda, P. (2011). Entrepreneurs' motivational factors: Empirical Evidence from Serbia. Serbian Journal of Management, 6(1), 73-83.

Stone, D. N. (1994). Overconfidence in initial self efficacy judgments: effect on decision process and performance. Organizational Behavior and Human Decision Processes, 59, 452-474.

Sule, E. K. (2006). Small scale industries in Nigeria: Concepts appraisal of some governments policies and suggested solutions to identified problems. Economic and Financial Review, 24(4), 24.

Tobak, S. (2013). Skills you need to be the next great entrepreneur. Accessed from wtp://www.inc.com/stevetobac/10-skills-toland_amanagement-job.html on $8^{\text {th }}$ April, 2014.

Umaru, D. M., and Obeleagu-Nzelibe, C. G. (2014). Entrepreneurship skills and profitability of small and medium enterprises (SMEs): Resource acquisition strategies for new ventures in Nigeria, Proceeding of $25^{\text {th }}$ International Business Research Conference, 13-14 January, Taj Hotel, Cape Town, South Africa.

Vancouver, J. B. \& Kendall, L. N. (2006). When self efficacy negatively related to motivation and performance in a learning context. Journal of Applied Psychology, 91(5), 1146-1153.X

Vancouver, J. B., Thompson, C. M., \& Williams, A. A. (2001). The changing signs in the relationship among self efficacy, personal goals and performance. Journal of Applied Psychology, 86(4), 605-620.

Vancouver, J. B., Thompson, C. M., Tischner, E., \& Putka, D. J. (2002). Two studies examining the negative effect of self efficacy on performance. Journal of Applied Psychology, 87(3), 506-516.

Ward, W. T. (2004). Cognition, creativity, and entrepreneurship. Journal of Business Venturing, 19, 173-188.

Zhao, H., Seibert, S. E., \& Hills, G. E. (2005). The mediating role of self- efficacy in the development of entrepreneurial intentions. Journal of Applied Psychology, 90(6), 1265-1272.X

Zimon, G. (2018). Influence of group purchasing organizations on financial situation of Polish SMEs. Deconomia Coperilana, 9(1), 87-104. 